\title{
THE USE OF HYPERVARIABLE GENOMIC DNA LOCI FOR GENDER DETERMINATION
}

\author{
$\mathcal{B Y}$ \\ Amani F. Hanon, Nevein A. EL Dessouky and Amany M. Ahmed* \\ Departments of Forensic medicine and Clinical Toxicology \\ Faculty of medicine, Cairo University and Beni Sueif University*.
}

\begin{abstract}
Blood stains identification at the scene of the crime using different old methods was known for a long time. Recently, DNA technology has provided novel and powerful methods for analysis of DNA isolated from forensic biological evidence that provides valuable information related to individual identification. In this study, Sex determination of the blood samples either, clotted, or unclotted, and serum samples were done through extraction of DNA both immediately from the tested samples and after their preservation at $25^{\circ} \mathrm{C}$ and $45^{\circ} \mathrm{C}$ for 3 days and 21 days. All extracted DNA were undergone PCR amplification for amelogenin, SRY, and androgen receptor sequences followed by their identification by electrophoresis and photographing by UV rays. Results showed that blood samples extracted immediately from the scene of the crime and clotted samples discovered at the scene of the crime up to 21 days at temperatures $25^{\circ} \mathrm{C}$ and $45^{\circ} \mathrm{C}$ were suitable for DNA extraction and sex determination. While samples that were preserved with anticoagulants can be used for sex determination within 3 days at $25^{\circ} \mathrm{C}$ while at $45^{\circ} \mathrm{C}$ preserved samples were not suitable for DNA identification. Serum samples tested with the same technique were not suitable for sex determination.
\end{abstract}

\section{INTRODUCTION}

Human body fluids such as blood and saliva are the most common sources of biological trace material found at a crime scene. Blood stains are routinely tested in forensic practice using various old methods. These methods depended upon the peroxidase-like activity of the heme unit of the hemoglobin molecule in human blood. (Creamer et al., 2005). They were presumptive, thus indicative but not iden- tifying methods because they depended on the peroxidase-like activity of the heme unit of the hemoglobin molecule in human blood. Therefore, false-positive results can be caused by the presence of strong oxidants, such as chlorine-containing detergents or by true peroxides (e.g., from plants)(Kent et al., 2003).

DNA technology has provided some novel and powerful methods for forensic science application. The analysis of DNA 
isolated from forensic biological evidence provides valuable information related to individual identification. For sex identification of bloodstains, bleached skeletons and teeth, Southern blot hybridization with Y-chromosome specific probe (pHY10; $3.4 \mathrm{~kb}$ ) and PCR amplifying with sex chromosome specific fragments can be used, (Misawa, 1994).

Hyper variable DNA loci have been widely applied especially in individual identification (Giusti et al., 1986) and in paternity tests (Baired et al., 1986). Most of them are multi locus probes that recognize several loci under reduced stringency. The statistical evaluation of the multi locus system is very difficult due to the undefined chromosomal location and is subjected to several assumptions (Odelberg et al., 1988). On the other hand the single locus probe is handled with high stringency, and is more sensitive and more capable of reproducing than in the multi locus probe (Yokoi et al., 1990). Postmortem degradation of DNA is a complex phenomenon, beginning with autolysis and followed by aerobic and bacterial destruction of the cells (Ludes et al., 1993). Physical and chemical degradation can destroy most of the DNA (Yang and Watt, 2005). Physical influences may include humidity, irradiations, photoelectric influences, but the most frequent physical influence has been always the temperature (Richardson et al., 2006).
The present study detect the possible effects of variations in temperature and duration of time on preserved blood samples, either clotted, un clotted or serum, that may impact the ability to extract genomic DNA -in sufficient quality for use in the polymerase chain reaction (PCR).

This study aiming to determine the optimal conditions suitable for obtaining data in molecular studies related to sex determination through detection of amelogenin, SRY and androgen receptor sequences in the extracted DNA, by electrophoresis after their quantification by PCR technique.

\section{PATIENTS AMD METHODS}

This study was performed in Reproduction Researches Institute Labs of veterinary faculty of medicine.

For this study, blood samples were collected from out patients of clinical pathology department, Kaser EL Aini Hospital : All individuals of this study are of normal appearance related to their sexes (no apparent congenital anomalies), of good health and gave consent about this study. They included:

1- Eight fresh unclotted blood samples taken from eight different males kept on EDTA containing tubes, $10 \mathrm{ml}$ each.

2- Eight fresh un clotted blood samples 
taken from eight different females kept on EDTA containing tubes, 10 ml each.

3- Eight fresh clotted blood samples taken from eight different males 10 $\mathrm{ml}$ each.

4- Eight fresh clotted blood samples taken from eight different females 10 ml each.

5- Each sample was further subdivided to three equal samples, so each group of blood will involve 24 samples that were classified into :

- Four samples used for immediate extraction and identification of DNA and used as a control group.

- Four samples undergo centrifugation for serum separation that used for immediate extraction and identification of DNA.

- Four samples stored at $25^{\circ} \mathrm{C}$ for 3 days.

- Four samples stored at $25^{\circ} \mathrm{C}$ for 21 days.

- Four samples stored at $45^{\circ} \mathrm{C}$ for 3 days.

- Four samples stored at $45^{\circ} \mathrm{C}$ for 21 days.

DNA would be extracted, purified and estimated from all the tested samples.

PCR amplification would be applied in all extracted DNA followed by DNA identification using electrophoresis.

\section{PROCEDURE}

I - DNA extraction, purification and estimation :

For DNA extraction from the blood samples and serum samples, the QIA amp method (2007)was used according to manufacturer recommendations with minor modification as follows: 1-Two step centrifugation. 2-Volume reduction(Gill et al., 1987).

After removal of the extract there is always residual amount of DNA containing substrate in the tube, re-suspension of the substrate in distilled water reduces this loss of DNA. The resulting concentration of DNA expected is often very low $<1 \mathrm{ug} /$ $\mathrm{ml}$ which means that the efficiency of ethanol precipitation can be as low as $70 \%$ (Zeugin and Hartley, 1985). To avoid this, washing with two buffers solutions and centrifugation time was extended up to 30 minutes.

Steps of the procedure: All kits used in this procedure are from the QIAGEN Group, USA.(Kits for genomic DNA purification from blood and body fluids) (cat. no 51104). 200 $\mu$ l of serum or blood samples were put into a $1.5 \mathrm{ml}$ micro centrifuge tube, $+20 \mu$ l proteinase $\mathrm{K}$ stock solution $(20 \mathrm{mg} / 1)+200 \mu \mathrm{l}$ buffer AL ( a second buffer provided in the kit) to each tube, incubate at $56^{\circ} \mathrm{C}$ for 10 minutes then $200 \mu \mathrm{l}$ of ethanol (96-100\%) were added to each sample and mix thoroughly by vortex 
with briefly spin. The mixture was then loaded in QIA amp mini spin column and centrifuge at $8000 \mathrm{rpm}$ for 1 minute.

The column material was washed twice (250 $\mu 1$ each) with the first washing buffer

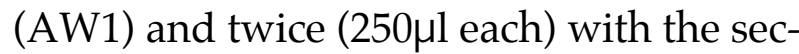
ond washing buffer (AW2) provided in the kit. At each step, place the QIA amp Mini spin column in a clean $2 \mathrm{ml}$ collection tube, close the cap and centrifuge at 8000 rpm for 1 minute, then discard the collection tube containing the filtrate. Finally the DNA was re-suspended in $100 \mu$ l of distilled water, incubate at room temperature for 1 minute and centrifuge at 8000 rpm for 30 minutes.

Serum and other body fluids (CSF, urine, and saliva) often contain very low number of cells; in these cases concentrating samples from up to $3.5 \mathrm{ml}$ to a final volume of $200 \mu 1$ is recommended. This step needs additional equipments as centrifugal micro concentrators such as Amicon centricon 100 (Millipore, $2 \mathrm{ml}$ ), Microsep 100 (Filtron, 3.5ml) and Ultra free - CL (Millipore, 2ml).

Procedure of concentrating the sample: Apply up to $3.5 \mathrm{ml}$ sample to the micro concentrator and centrifuge " according to manufacturer instructions " to a final vol-

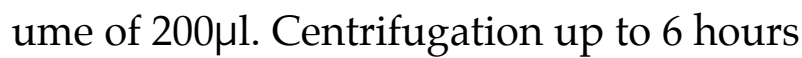
is recommended due to the high viscosity of the sample. Pipette $200 \mu 1$ of the concen- trate into a $1.5 \mathrm{ml}$ micro centrifuge tube and follow the previous protocol.

\section{II- PCR amplification for amelogenin,} $S R Y$ and androgen receptor sequences:

The PCR amplification protocol was designed to allow simultaneous amplification of the SRY and AR genes in a single $25 \mu 1$ reaction tube (Multiplex PCR).

After denaturizing for 5 minutes at $94^{\circ}$ C, 28 cycles were performed as follow denaturizing at $94^{\circ} \mathrm{C}$ for 1 minute, annealing at $61^{\circ} \mathrm{C}$ for 2 minutes and extension at $69^{\circ}$ $\mathrm{C}$ for 2 minutes followed by final extension of 10 minutes at $70^{\circ} \mathrm{C}$.

The PCR products were electrophoresd on $1 \%$ ethidium bromide stained agarose gel at 5 minutes and photographed under UV light.

The Y specific SRY primers used were

XES10 : 5' GGTGTTGAGGGCGGAGAAATGC-3' (forward) and

XES11 : 5' GTAGCCATTGTTACCCGATTGTC-3' (reverse) that yield $779 \mathrm{bp}$ products.

The $X$ specific AR gene primers (exon 6) used were

6A: 5'- CTC TGG GTT ATT GGT AAA

CTT CC-3' (forward) and

6B: 50- GTC CAG GAG CTG GCT TTT CCC TA-3' (reverse) that yield 292 bp products. 
RESULTS

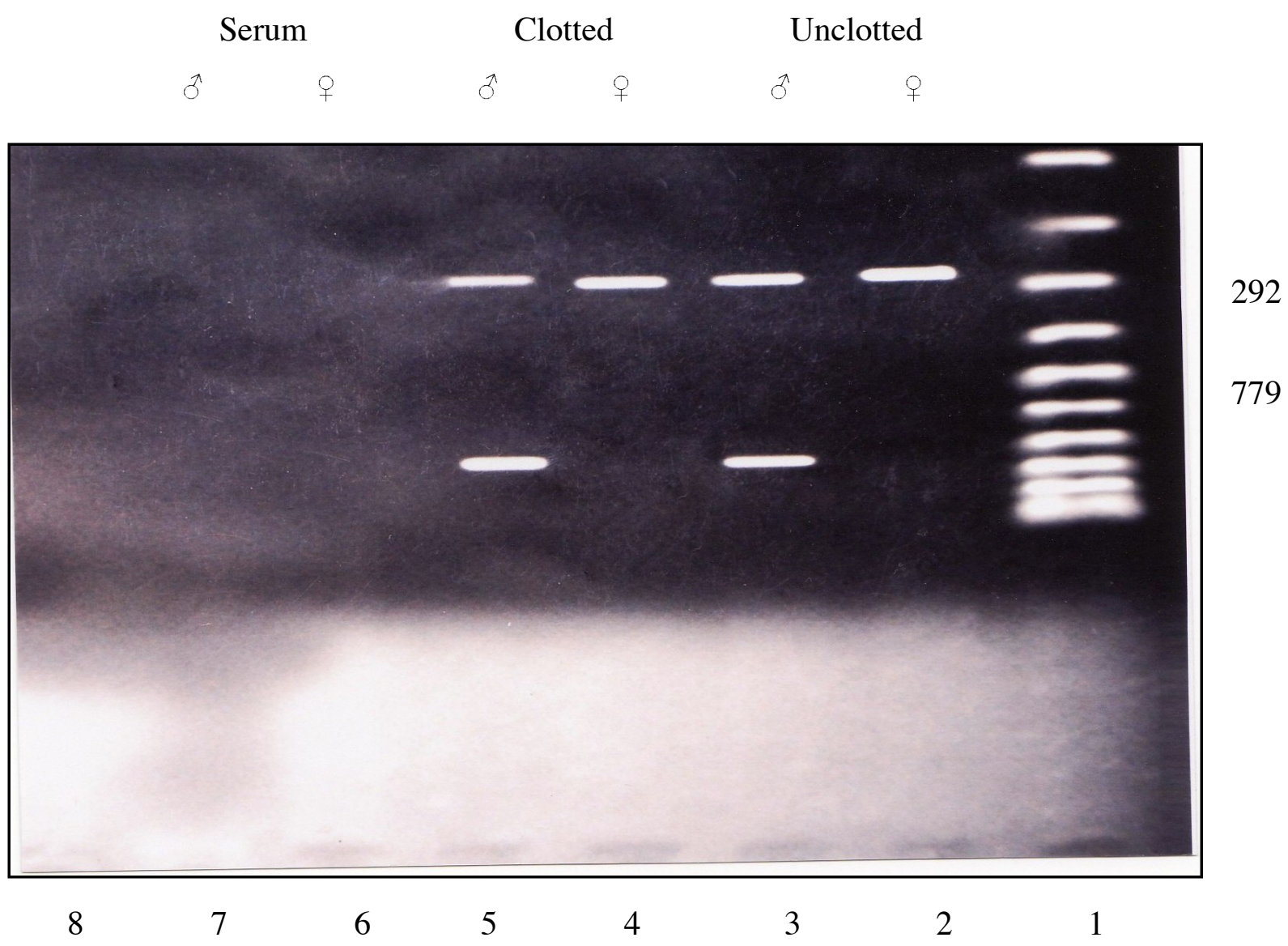

Figure (1): Shows a representative agarose gel electrophoreses of gene prediction by a conventional PCR analysis of immediately extracted unclotted, clotted blood and serum samples from females and males. The amplified products of the AR sequence on X chromosome and the SRY sequence on Y chromosome are 292 and 779 bp in length respectively. Results obtained on genomic DNA sample prepared from female unclotted sample (lane 2), male unclotted sample (lane 3), female clotted sample (lane 4), male clotted blood (lane 5), female serum (lane 6) (-ve result), male serum (lane 7) (-ve result). (Lane 1):100 bp DNA marker and (lane 8): Negative control. 


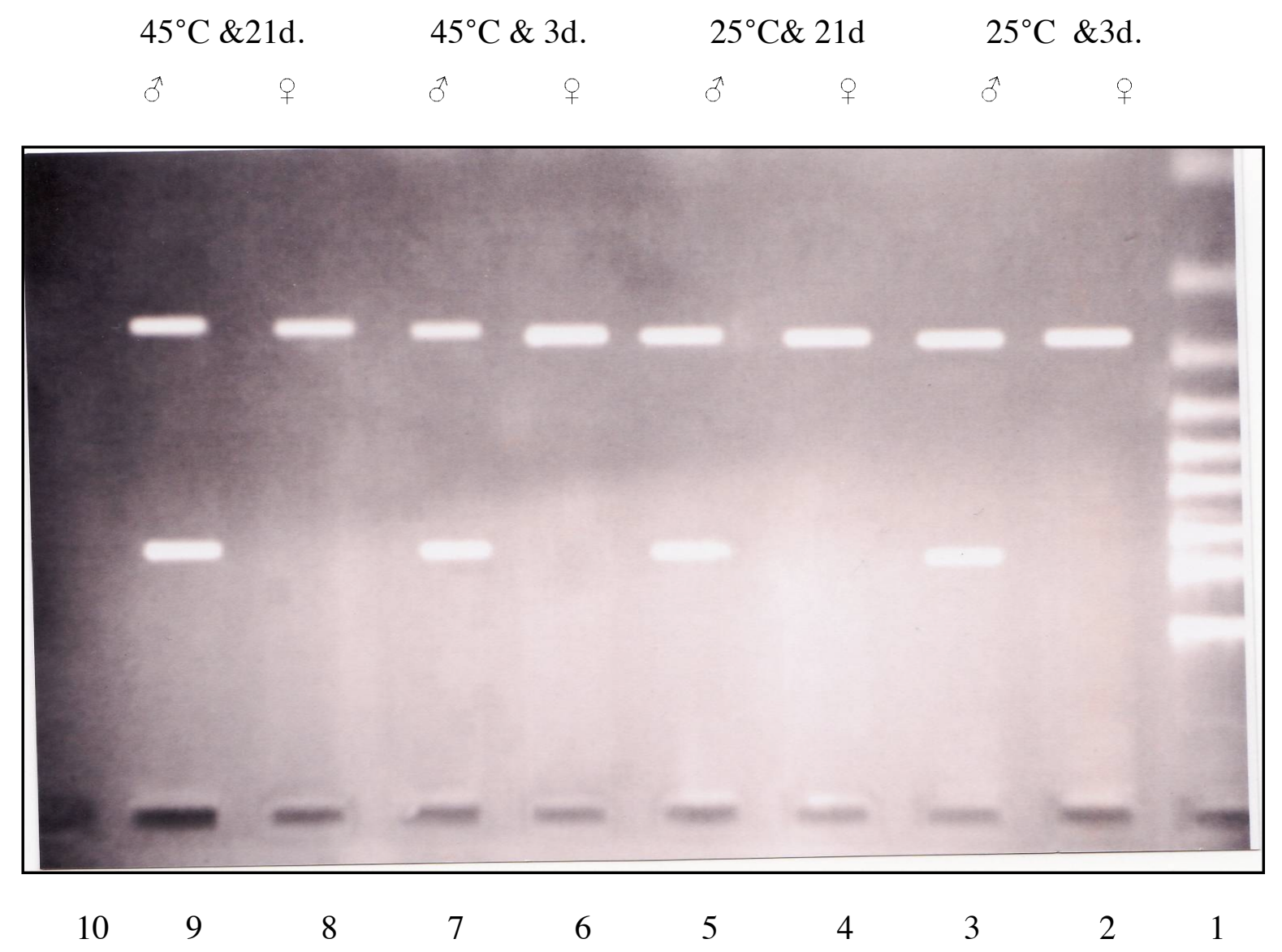

Figure (2) : Shows a representative agarose gel electrophoreses of gene prediction by a conventional PCR analysis of extracted preserved clotted blood samples from males and females. The amplified products of the AR sequence on x chromosome and the SRY sequence on Y chromosome are 292 and 779 bp in length respectively. Results obtained on genomic DNA sample prepared from female clotted blood after 3 days at $25^{\circ} \mathrm{C}$ (lane 2), male clotted blood after 3 days at $25^{\circ} \mathrm{C}$ (lane 3), female clotted blood after 21 days at $25^{\circ} \mathrm{C}$ (lane 4), male clotted blood after 21 days at $25^{\circ} \mathrm{C}$ (lane 5), female clotted blood after 3 days at $45^{\circ} \mathrm{C}$ (lane 6), male clotted blood after 3 days at $45^{\circ} \mathrm{C}$ (Lane 7) female clotted blood after 21 days at $45^{\circ} \mathrm{C}$ (lane 8), male clotted blood after 21 days at $45^{\circ} \mathrm{C}$ (lane 9), (Lane 1) :100 bp DNA marker and (lane 10): Negative control. 


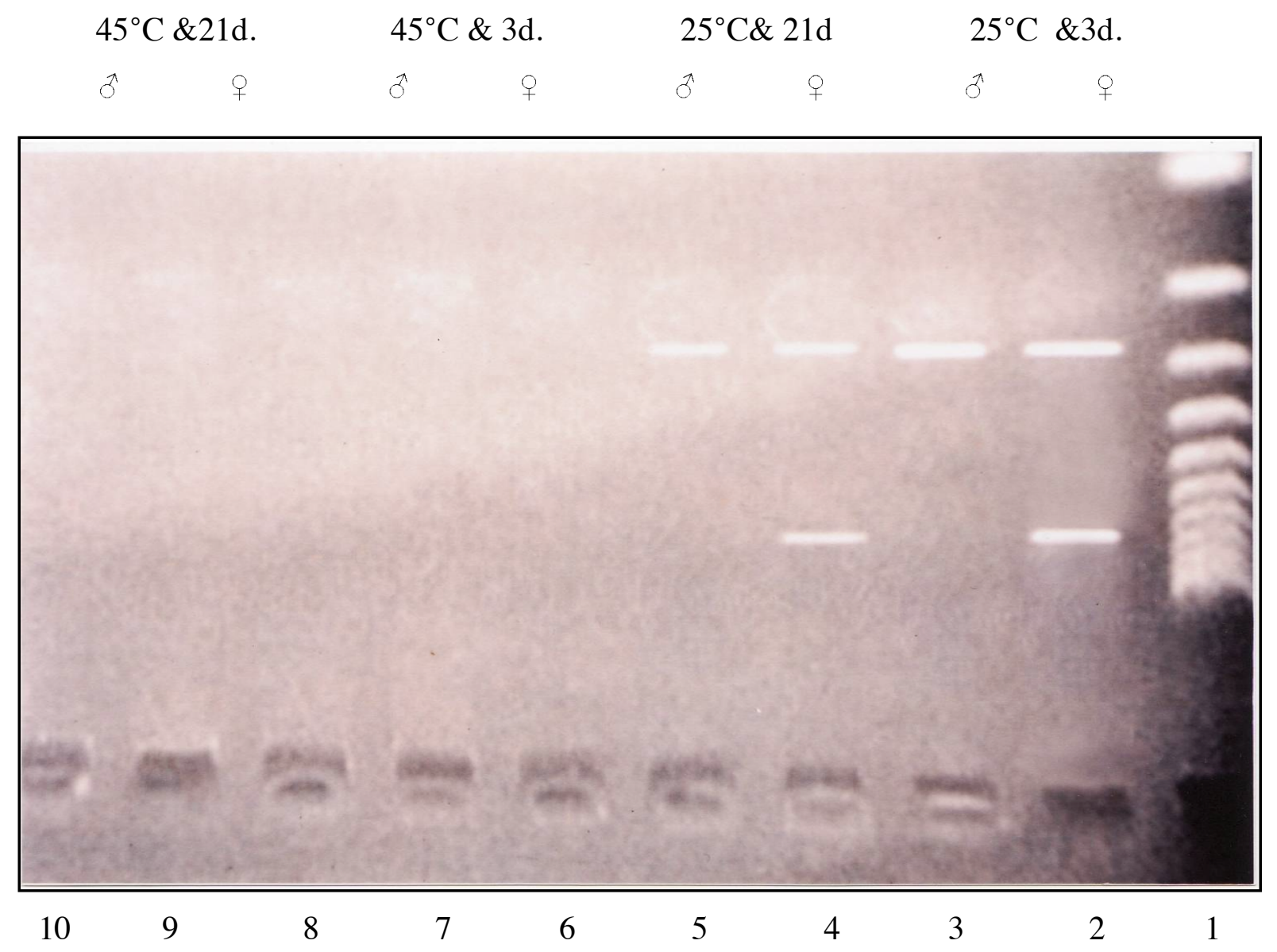

Figure (3) : Shows a representative agarose gel electrophoreses of gene prediction by a conventional PCR analysis of extracted preserved un clotted blood samples from males and females. The amplified products of the AR sequence on $x$ chromosome and the SRY sequence on Y chromosome are 292 and 779 bp in length respectively. Results obtained on genomic DNA sample prepared from male unclotted blood after 3 days at $25^{\circ} \mathrm{C}$ (lane 2), female un clotted blood after 3 days at $25^{\circ} \mathrm{C}$ (lane 3), male unclotted blood after 21 days at $25^{\circ} \mathrm{C}$ (lane 4), female blood unclotted after 21 days at $25^{\circ} \mathrm{C}$ (lane 5), male un clotted blood after 3 days at $45^{\circ} \mathrm{C}$ (Lane 6) (-ve result), female un clotted blood after 3 days at $45^{\circ} \mathrm{C}$ (lane 7) (-ve result), male unclotted blood after 21 days at $45^{\circ} \mathrm{C}$ (lane 8) (-ve result), female unclotted blood after 21 days at $45^{\circ} \mathrm{C}$ (lane 9) (-ve result), (Lane 1) : 100 bp DNA marker and (lane 10): Negative control. The study results in all cases showed that unclotted blood samples with EDTA preserved at high temperatures $45^{\circ} \mathrm{C}$ for short durations of time starting from 3 days up to 21 days were not suitable for DNA identification while those preserved at low temperature $25^{\circ} \mathrm{C}$ up to 21 days can be used for DNA identification and suitable for molecular identification in forensic study. Also serum samples are not suitable for DNA identification by the used technique. 


\section{DISCUSSION}

The polymerase chain reaction (PCR) technique has made it possible to amplify specific segments of DNA. A major advantage of this technique is the ability to identify DNA even from minute quantities of samples. Thus the PCR technique is a powerful tool in routine forensic practice for the identification of individuals. (Reynolds and Sensabaugh, 1991).

In this study, DNA extraction and identification from the immediately clotted blood samples and from those preserved at $25^{\circ} \mathrm{C}$ and $45^{\circ} \mathrm{C}$ for short duration of time up to 21 days can be done in all tested specimens using PCR and electophoresis. These results coincide with the results of Semba et al., (1994), who reported that, $X$ and $Y$ specific sequences could be detected even from blood specimen left at room temperature for seven months.

Emanuel and Pestka, (1993), reported that DNA obtained from serum may be released from healthy cells that remain in the serum or from cells that have ruptured.

In the present study immediate DNA extraction from serum samples by the used QIAamp method gives no results. This may be explained by Kamm and Smith, (1972) and Dennin, (1979), who reported that the estimation of DNA concen- tration in human plasma and / or serum has been attempted by various methods and the results have varied considerably largely depending on the applied methods.

On the other hand, Tomohiro et al., (2001), reported that DNA concentration in serum increased in blood stored up to eight days at room temperature there are ladder patterns on agarose gel electrophoresis that become more apparent with storage time. This is explained by apoptotic neutrophils fragments released cleaved DNA into serum and fragmented DNA increased progressively with time. In apoptosis double strand nuclear DNA is cleaved by endogenous endonuclease at the linker regions between nucleosomes leading to the production of oligonucleosomal fragments (Kerr et al.,1994). Studies have suggested that circulating neutrophilis " which account for most leucocytes and have half life of less than 10 hours " (Dancey et al., 1976) undergo apoptosis in the vasculature (Matsuba et al., 1997). Thus serum apparently contain fragmented DNA that is derived from the apoptosis of leukocytes especially neutrophils.

Regarding the unclotted blood samples the study results showed the possibility of using these samples for DNA identification in cold " moderate environmental temperatures up to $25^{\circ} \mathrm{C}$ while in hot tem- 
peratures these samples are not suitable which could be explained by a lack of sufficient amounts of DNA (Shutler et al., 1999) or the presence of inhibitors as described by Johannes et al. (2009), who reported that diagnostic DNA analysis, including forensic applications, is often limited by components that interfere with the amplification, so-called " PCR inhibitors ".

Some inhibitors factors are related to commercial DNA typing kits including primers DNA polymerase and buffer that used almost exclusively throughout the world. Amp FISTR SGM Plus and Power Plex 16 are two of the most commonly used kits. Such DNA typing kits simplify the standardization and comparison of DNA profiles across borders and enable relatively straightforward validation for each laboratory, compared with the use of in-house assays. However, the complete chemical content of the kits is not disclosed, making PCR chemistry a "black box." Due to the wide use of this analysis kits, modifying PCR chemistry to reduce the effects of inhibition has become rare in the field of diagnostic
PCR (Radstrom et al., 2004).

In forensic, only some minor DNA typing studies with alternative polymerases have been performed and mainly on pure standard DNA (Spitaleri et al., 2004).

Other factors are related to blood samples as: Aluminum cans may release $\mathrm{Al} 3+$ ions, which can inhibit PCR (Wadowsky et al. 1994), while tobacco contains about 4000 chemical compounds, several of which may have inhibitory effects, such as formaldehyde (Johnson et al., 1995) and phenols (Katcher and Schwartz, 1994). Cigarette filter paper may also have a negative effect since components of wood are known to inhibit PCR (Lee and Cooper, 1995).

It is concluded from our study that sex determination from the preserved clotted blood samples using the available QIamp method is possible up to 21 days and $45^{\circ}$ C while for the unclotted samples with EDTA or serum samples, this technique is not suitable so other techniques may be tried. 


\section{REFERENCES}

Baired, M.; Balazs, I.; Miazaki, L. and Nicholas, L. (1986) : "Allelic frequency distribution of two highly polymorphic DNA sequences in three ethnic groups and its application to the determination of paternity". Am. J. Hum. Genet., 39:489-501.

Creamer, J. I.; Quickenden, T. I.; Crichton, L. B.; Robertson, P. and Ruhayel, R. A. (2005) : "Attempted cleaning of blood stains and its effect on the forensic luminol test". Luminescence, 20(6):411-413.

Dancey, J. T.; Deubelbeiss, K. A.; Harker, A. L. and Finch, C. A. (1976) : "Neutrophils kinetics in man". J. Clin. Invest., 58:705-715.

Dennin, R. H. (1979) : "DNA of free and complex origin in human plasma concentration and length distribution". Klin. Wochenschr, 57:451-456.

Emanuel, S. L. and Pestka, S. (1993) : "Amplification of specific gene products from human serum". Genet. Anal. Tech. Appl., 10:144-146.

Gill, P.; Lygo, J. E.; Fowler, S. J. and Werrett, D. J. (1987) : "An evaluation of DNA finger printing for forensic purposes". Electrophoresis, 8: 38-44.

Giusti, A.; Baird, M.; Pasqule, S.; Ba- lazs, I. and Glassberg, J. (1986) : "Application of deoxyribonucleic acid (DNA) polymorphism to the analysis of DNA recovered from sperms". J. Forensic Sci., 31: 409-417.

Johannes, H.; Anders N.; Birgitta R.; Ricky A. and Peter R. (2009) : "Improved forensic DNA analysis through the use of alternative DNA polymerases and statistical modeling of DNA profiles". J. Bio Techniques, 47(5) 951-958.

Johnson, D. W.; Pieniazek, N. J.; Griffin, D. W.; Misener, L. and Rose, J. B. (1995) : "Development of a PCR protocol for sensitive detection of Cryptosporidium oocysts in water samples". Appl. Environ. Microbiol., 61:3849-3855.

Kamm, R. C. and Smith, A. G. (1972) : "Nucleic acid concentration in normal human plasma". Clin. Chem., 18:519-522.

Katcher, H. L. and Schwartz, I. (1994) : "A distinctive property of $\mathrm{T}^{\text {th }}$ DNA polymerase enzymatic amplification in the presence of phenol". Bio Techniques, 16:84-92.

Kent, E. J.; Elliot, D. A. and Miskelly, G. M. (2003) : "Inhibition of bleachinduced luminol chemiluminescence". J. Forensic Sci., 48(1):64-67.

Kerr, J. F.; Winterford, C. M. and Har- 
mon, B. V. (1994) : "Apoptosis: its significance in cancer and cancer therapy". Cancer, 73:2013-2026.

Lee, A. B. and Cooper, T. A. (1995) : "Improved direct PCR screen for bacterial colonies: wooden toothpicks inhibit PCR amplification". Bio Techniques, 18 : 225226.

Ludes, B.; Pfitzinger, H. and Mangin, P. (1993) : "DNA fingerprinting from tissues after variable postmortem periods". J. Forensic Sci., 38: 686-690.

Matsuba, K. T.; Vaneeden, S. F.; Bicknell, S. G.; Walker, B. M.; Hayashi, S. and Hoggy, J. C. (1997) : "Apoptosis in the circulating PMN; increased susceptibility in L-selectin deficient PMN". AMJ. Physiol., 272 : 2852-2858.

Misawa, S. (1994) : "Application of DNA polymorphism to forensic medicine". Journal of Rinsho Byori., 42 (6) : 636-42.

Odelberg, S. J. ; Demers, D. B.; Westen, E. H. and Hossaini, A. A. (1988) : "Establishing paternity using minisatellite DNA probes when the putative father is unavailable for testing". J. Forensic Sci., 33: 921-928.

QIA amp method (2007) : "DNA purification from blood and body fluids, spin protocol". QIA amp DNA mini and blood mini handbook Second edition, USA: 2730.

Radstrom, P.; Knutsson, R.; Wolffs, P.; Lövenklev, $M$. and Lofstrom, C. (2004): "Pre-PCR processing: strategies to generate PCR-compatible samples". Mol. Biotechnol., 26:133-146.

Reynolds, R. and Sensabaugh, G. (1991): "Analysis of genetic markers in forensic DNA samples using the polymerase chain reaction". Anal. Chem., 63:2-15.

Richardson, A. J.; Narendran, N. R.; Vu, H.; and Baird, P. N. (2006) : "Blood storage at $4{ }^{\circ} \mathrm{C}$ "factors involved in DNA yield and quality". Paul. N. Journal of Laboratory and Clinical Medicine, 147 (6): 290-294.

Semba, S.; Yamamoto, Y. and Ishizu, H. (1994) : "Sex determination from blood and bloodstains by polymerase chain reaction (PCR)". J. Nihon Hoigaku Zasshi., 48 (1):7-18.

Shutler, G. G.; Gagnon, P.; Verret, G.; Kalyn, H.; Korkosh, S.; Johnston, E. and Halverson, J. (1999) : "Removal of a PCR inhibitor and resolution of DNA STR types in mixed human-canine stains from a five year old case". J. Forensic Sci., 44 : 623-626. 
Spitaleri, S.; Piscitello, D.; Di Martino, D. and Saravo, L. (2004) : "Experimental procedures comparing the activity of different Taq. Polymerases". J. Forensic Sci. Int., 146:S167-S169.

Tomohiro, T.; Sadao, Y.; Yoshihisa, W. and Kiji, H. (2001) : "Origin of DNA in human serum and usefulness of serum as a material" J. Legal Medicine, 3: 109-113.

Wadowsky, R. M.; Laus, S.; Libert, T.; States, S. J. and Ehrlich, G. D. (1994) : "Inhibition of PCR-based assay for Bordetella pertussis by using calcium alginate fiber and aluminum shaft components of a nasopharyngeal swab". J.
Clin. Microbiol., 32:1054-1057.

Yang, D. Y. and Watt, K. (2005) : "Contamination control when preparing archaeological remains of ancient DNA analysis". Journal of Archaeological Science, 32: $331-336$

Yokoi, T.; Kimura, T. and Sagisaka, K. (1990) : "Individual identification of human blood stains investigated with hypervariable DNA loci". Tohoku J. Exp. Med., 161(1): 9-18

Zeugin, J. A. and Hartley, J. L. (1985) : "Ethanol precipitation of DNA". Focus, 7:1-2. 


\section{إستخدام هـواضع عتعددة هـن الحاهض النوونى لتحديد الجنس}

$$
\text { المشتركون فى البحث }
$$

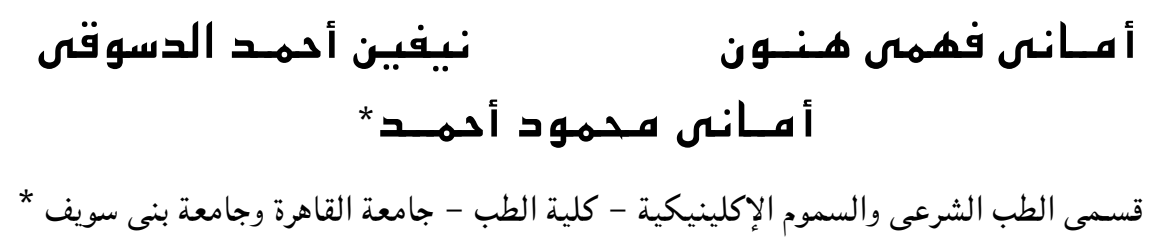

إن الطرق القديمة المستـدمة فى التعرف على عينات الدم التى توجد فى مسرح الجريمة تعتمد أساساً على وجود إنزيم البيروكسيداز فى الهيموجلوبين فى الدم فى بعض الأحيان هذه الطرق تعطى نتائج إيجابية خاطئة نتيجة لوجود بعض المواد المؤكسدة فى الدم مثل المواد المؤكسدة فى بعض النباتات، ولكن التكنولوجيا الحديثة فى مجال التعرف على الحامض النووى أظهرت إيساد طرق جديدة للتعرف على الأشخاص من خلال عينات الدم عن طريق إمكانية فصل جزء من الحامض النووى ثم تكاثره لعدة أجزاء باستخدم بى سى آر والتعرف على الجينات الخاصة فى الحامض النووى بواسطة جهاز الكتروفوريسز. فى هذا البحث تم إستخدام عيـنات دم متجلط وغير متجلط وعينات من السيرم (السائل الدموى) بعد حفظها فى درجات حرارة مختلفة عند ro و مع درجة مئويـة لمدة ثلاثة أيسام وواحد وعشرون يوماً ثم تم فصل الحامض النووى من جميع العينـات والتعرف على مستـبلات إميلوجينين واس ار واى والأندروجين (والنى يمن منها تحديد الجنس) باستخدام جهاز الكتروفوريسز ثم تصويرها بالأشعة الفوق بنفسجية. أظهرت النتائج أن عينات الدم المتجلط التى أخذت مباشرة والتى تم حفظها فى درجات حرارة ro و Oع حتى اب يوماً أمكن فصل الحامض النووى منها والتعرف على الجينات الخاصة لتحديد الجنس أما عينات الدم الغير متجلطة أعطت نتائج سلبية ولكن يمكن تحديد الجنس منها إذا

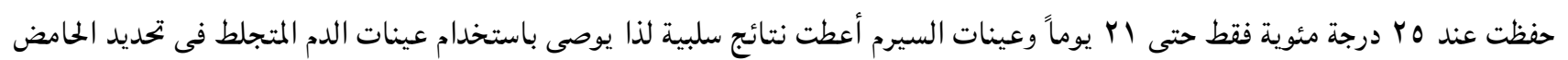
النووى كما ينصح بعمل دراسات أخرى باستخدام طرق أخرى لإمكانية فصل الحامض النووى من السيرم (السائل الدموى). 